\title{
Selection protocols for increased yield and stress tolerance in common bean ${ }^{1,2}$
}

\author{
James R. Smith ${ }^{3}$ \\ J. Agric. Univ. P.R. 88(1-2):27-43 (2004) \\ ABSTRACT
}

Selection protocols are needed to assess yield potential and stress tolerance among diverse common bean (Phaseolus vulgaris L.) progenies derived from wide crosses. The objective of this study was to assess the value of using geometric means of stressed and non-stressed yield trials and deviations from regression of stressed yield regressed onto non-stressed yield to select for yield potential and stress tolerance among highly diverse common bean lines. Short single-row plots in multiple environments (stressed and non-stressed) were used for evaluation. Seed yield was measured for forty-eight diverse common bean lines grown in four field trials in Puerto Rico. Two trials were stressed with soil compaction, waterlogged soil, and a bean monoculture, whereas the other two trials (non-stressed) did not receive the above stress treatment. Geometric means were effective in differentiating the highest yielding lines across environments. Deviations from regression were effective in identifying lines with stress tolerance, but not necessarily so in identifying tolerant lines with yield potential. In many instances, selection based on geometric means and deviations from regression identified different lines. On the basis of the evaluation of these 48 diverse lines, geometric means of multiple environments (stress and nonstress) are recommended for the yield evaluation of highly diverse progenies from wide crosses.

Key words: common bean, Phaseolus vulgaris, short-row plots, stress, yield selection

\section{RESUMEN}

Métodos de selección para aumentar el rendimiento y la tolerencia al estrés en la habichuela común

Se necesitan métodos de selección para evaluar el potencial de rendimiento y la tolerencia al estrés de progenies diversas de habichuela común (Phaseolus vulgaris L.) provientes de padres muy distintos. El objetivo de este estudio fue comparar el valor del promedio geométrico de rendimiento (entre localidades con y sin estrés) y desviaciones de regresión del rendimiento con y sin estrés para seleccionar el potencial de ren-

${ }^{1}$ Manuscript submitted to the Editorial Board 30 April 2003.

${ }^{2}$ The author is grateful to Wanda I. Almodóvar, Extension Phytopathology Specialist of the University of Puerto Rico, for isolating and identifying specimens of Rhizoctonia and Fusarium from field trials. The author thanks Adolfo Quiles and José Santiago for technical assistance. For statistical assistance the author thanks Raúl Macchiavelli, Ph.D. (University of Puerto Rico) and Deborah Boykin (USDA-ARS, Stoneville, MS).

${ }^{3}$ Research Geneticist, USDA-ARS, 141 Experiment Station Road, P.O. Box 345, Stoneville, MS 38776. E-mail: rsmith@ars.usda.gov. 


\begin{abstract}
dimiento y la tolerencia al estrés entre líneas diversas de habichuela común. Se utilizaron parcelas de un surco corto en múltiples localidades. Se obtuvieron datos de rendimiento para 48 líneas diversas de habichuela común en cuatro localidades en Puerto Rico. Dos de los ensayos se sometieron al estrés de compactación del suelo, agua excesiva, y monocultivo de habichuela, mientras que los otros dos ensayos no se sometieron a ninguna de estas condiciones. Los promedios geométricos entre ensayos con y sin estrés diferenciaron efectivamente las líneas de alto rendimiento en los diversos tipos de ambientes. Las desviaciones de regresión identificaron efectivamente las líneas con tolerencia al estrés, pero no necesariamente aquéllas de alto rendimiento. En muchos de los casos, los promedios geométricos y las desviaciones de regresión seleccionaron líneas diferentes. Con base en la evaluación de estas 48 líneas distintas, se recomienda el uso de promedios geométricos de ambientes múltiples para la evaluación de progenies diversas provientes de padres muy distintos.
\end{abstract}

Palabras clave: habichuela común, frijol, Phaseolus vulgaris, estrés, selección, rendimiento

\title{
INTRODUCTION
}

A common objective of many breeding programs is the broadening of the genetic base of crop plants for yield and stress tolerance through the use of promising unadapted germplasm and by making inter-specific and inter-gene pool hybridizations. Kelly et al. (1998) envisioned the broadening of common bean germplasm as occurring in an organized and step-wise manner. They illustrated the concept as a pyramid: Genes move from the base of the pyramid (unadapted germplasm) to the apex of the pyramid (adapted elite temperate cultivars). On the base level, new genes and gene combinations from tropical, climbing, photoperiod-sensitive accessions are introgressed through population development and selection into temperate-adapted germplasm at the intermediate level. Continued population development and selection of genetic material at the intermediate level will introgress new genes and gene combinations into the apex level, where the best gene combinations become integrated into new cultivars.

Puerto Rico (approximately 18 to $19^{\circ} \mathrm{N}$ Latitude) provides an ideal location for common bean research at the base and intermediate levels of the breeding pyramid (Kelly et al., 1999; Miklas, 2000). Tropical, climbing, photoperiod-sensitive germplasm can be evaluated along with temperate, photoperiod-insensitive types. Population development can occur between bush and climbing types, between photoperiodsensitive and -insensitive types, between snap and dry types, and across races, gene pools, and species. Unique gene combinations can be created and introgressed into established temperate market classes.

After the creation of such unique and diverse populations, effective selection schemes must be developed and utilized to identify new genotypes with yield potential and stress tolerance. Superior common bean 
cultivars at the apex of the pyramid will need to perform well under both stressful and non-stressful environments and will need tolerance to both biotic and abiotic stresses. Both stressed and non-stressed trials need to be included in the selection scheme.

Galwey and Evans (1982) recommended utilizing deviations from the regression of stressed yield on non-stressed yield to identify common bean lines with tolerance to the leafhopper Empoasca kraemeri (Ross and Moore). Beebe et al. (1997) used deviations from regression to identify phosphorus-efficient common bean lines grown in low phosphorus soils. Beebe et al. (1997) pointed out the following advantages for using deviations from regression: 1) Deviations from regression are measured in the same units as yield and therefore indicate the actual amount of yield that can be attributed to tolerance; 2) A strict experimental relationship between the two variables is not required; and 3) Regression analysis can be applied with data from different sites or planting seasons. A fourth advantage is that genotypes of widely differing yield potentials, such as when comparing land races with released cultivars or when comparing across growth habits, can effectively be compared together (S. Beebe, personal communication, 2001). Hence, deviations from regression are particularly appealing for evaluating diverse populations developed between exotic and temperate types.

A potential problem of selection for yield under stress is that it may result in reduced yield performance under non-stress (Rosielle and Hamblin, 1981; Schneider et al., 1997). To reduce the potential for this problem, Schneider et al. (1997) recommended selection based on the geometric mean of stressed performance and non-stressed performance, followed by selection under stress.

The ideal selection methodology should have the potential to be applied to small yield plots. This is important because in the development of pure-line cultivars of autogamous species, such as common bean, there is at least one generation in which the progeny of single plants will be evaluated. Seed quantities from single-plant-derived progenies usually do not permit the use of bordered replicated plots. However, breeders can still yield-test single-plant progenies to determine the best lines for further testing.

Green et al. (1974) recommended short (1.02-m) single-row plots for predicting soybean (Glycine max L. Merr.) yield performance in larger bordered plots. St. Martin et al. (1990) recommended short (1.5-m) single-row single-replication plots at two or more locations for determining yield selection among single-plant soybean progenies. This testing might be feasible in early $\left(\mathrm{F}_{2: 3}, \mathrm{~F}_{3: 4}\right)$ or later $\left(\mathrm{F}_{4: 5}, \mathrm{~F}_{5: 6}\right)$ generations. The number of environments used will be limited by the amount of seed produced per selected single plant. Kelly et al. (1999) 
questioned the value of early-generation yield testing for common bean breeding programs with limited yield-testing resources. However, they cited its success for yield testing across locations and in combination with other breeding systems to evaluate $\mathrm{F}_{2}$ and $\mathrm{F}_{3}$ populations across contrasting locations.

Deviations from regression were successfully utilized in common bean to select for biotic (Galwey and Evans, 1982) and abiotic (Beebe et al., 1997) stress tolerance. The use of geometric means was the best indicator of common bean yield under drought stress and non-drought stress (Schneider et al., 1997). Both methodologies utilized contrasting environments to select the best entries. However, no direct comparison of these two selection methodologies has previously been made. The purpose of this study was to use short single-row plots in multiple environments (stressed and non-stressed) to comparatively assess the value of using geometric means and deviations from regression to select for yield potential and stress tolerance among highly diverse bean genotypes (exotic land races, plant introductions, breeding lines, cultivars). This study was conducted in anticipation of the need for selection protocols to assess the highly unique and diverse populations developed from inter-racial, inter-gene pool, and inter-specific crosses as suggested by Kelly et al. (1999).

\section{MATERIALS AND METHODS}

Forty-eight diverse common bean lines (Table 1) of various growth habits (Singh, 1982), environmental adaptations, and seed types were selected and grown in four field trials. They consisted of six snap bean bush types (type I), eight dry bean bush types (type I), 31 dry bean nonclimbing vine types (types II and III), and three dry bean climbing vine types (type IV). The dry bean bush types consisted of two light red kidneys, one dark red kidney, one cranberry, and four plant introductions. Among the indeterminate types were 10 blacks, three pinks, six pintos, three whites, five small reds, and seven miscellaneous types. Seventeen cultivars from the United States were included. Twenty-three of the 48 entries were previously identified as resistant to Fusarium solani f. sp. phaseoli (Burk. Synd. and Hans.) and 11 entries were previously identified as resistant to Rhizoctonia solani (Kühn). Rhizoctonia solani is a major cause of damping off, and $F$. solani is a major cause of root rot in common bean (Beebe and Pastor Corrales, 1991). Both organisms can cause serious production problems for common bean in the temperate United States (Forster et al., 2000; Miklas, 2000).

Three of the four field trials were planted in Isabela, Puerto Rico ( $18^{\circ} 28^{\prime} \mathrm{N}$ Latitude; $126 \mathrm{~m}$ above sea level) in an Oxisol (Typic Haplu- 
TABLE 1. Means of seed yield of four field trials, two stressed field trials, two non-stressed field trials, the geometric mean of seed yield of two stressed and two non-stressed field trials, and mean deviations from regression for forty-eight common bean lines in Puerto Rico in 1999 .

\begin{tabular}{|c|c|c|c|c|c|c|c|}
\hline \multirow[b]{2}{*}{ Line } & \multirow[b]{2}{*}{$\mathrm{ST}^{1}$} & \multirow[b]{2}{*}{$\mathrm{GH}^{2}$} & \multicolumn{3}{|c|}{ Back-transformed mean seed yield } & \multirow[b]{2}{*}{$\begin{array}{l}\text { Geometric mean } \\
\text { seed yield }\end{array}$} & \multirow{2}{*}{$\begin{array}{l}\text { Back-transformed } \\
\text { mean deviations } \\
\text { from regression }\end{array}$} \\
\hline & & & Combined trials & $\begin{array}{c}\text { Non-stressed } \\
\text { trials }\end{array}$ & Stressed trials & & \\
\hline & & & 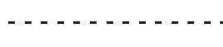 & 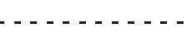 & - - (kg/ha) - & $-\cdots$ & $-\cdots$ \\
\hline G21212 & BL & 3 & 1,013 & 1,896 & 552 & 1,288 & 21 \\
\hline T-39 & BL & 2 & 861 & 1,650 & 447 & 1,175 & 26 \\
\hline MUS PM-31 & RM & 3 & 803 & 1,308 & 480 & 1,098 & 29 \\
\hline XAN 176 & BL & 3 & 714 & 1,940 & 259 & 1,157 & 4 \\
\hline A300 & B & 2 & 636 & 1,650 & 236 & 863 & 4 \\
\hline Rosita & LA & 3 & 593 & 1,308 & 259 & 991 & 8 \\
\hline Porrillo Sintético & BL & 2 & 565 & 1,087 & 285 & 885 & 12 \\
\hline BAT 477 & $\mathrm{C}$ & 2 & 503 & 1,165 & 219 & 863 & 6 \\
\hline DOR 364 & SR & 3 & 503 & 1,539 & 156 & 953 & 0 \\
\hline Honduras 46 & SR & 3 & 480 & 1,192 & 190 & 674 & 5 \\
\hline PI 165435 & BL & 3 & 447 & 784 & 259 & 763 & 15 \\
\hline PI 312033 & BL & 4 & 437 & 565 & 345 & 845 & 22 \\
\hline Montcalm & DK & 1 & 397 & 990 & 170 & 733 & 2 \\
\hline PI 109859 & SR & 1 & 397 & 766 & 204 & 752 & 10 \\
\hline G18252 & BL & 3 & 345 & 1,062 & 108 & 639 & -1 \\
\hline Turbo III & BL & 3 & 321 & 651 & 160 & 505 & 7 \\
\hline
\end{tabular}

1ST (Seed Type): $\mathrm{BL}=$ black, RM = red mottled, $\mathrm{B}=$ beige, $\mathrm{PK}=$ pink, $\mathrm{C}=$ creme, $\mathrm{SR}=$ small red, $\mathrm{DK}=$ dark red kidney, $\mathrm{PT}=$ pinto, $\mathrm{SK}=$ striped light red kidney, $\mathrm{LK}=$ light red kidney, $\mathrm{SW}=$ small white, $\mathrm{CR}=$ cranberry, $\mathrm{TN}=\tan , \mathrm{SN}=$ snap bean, $\mathrm{DB}=$ dark brown, $\mathrm{W}=$ white, $\mathrm{BW}=$ black and white, and $\mathrm{LA}=$ lavender.

${ }^{2} \mathrm{GH}$ (Growth Habit): 1 = bush, determinate, 2 = bush, indeterminate, 3 = indeterminate prostrate with well-developed branching but low or nonexistent climbing ability, and $4=$ indeterminate, with long guide and high climbing ability (Singh, 1982). 
TABLE 1. (CONTINUED) Means of seed yield of four field trials, two stressed field trials, two non-stressed field trials, the geometric mean of seed yield of two stressed and two non-stressed field trials, and mean deviations from regression for forty-eight common bean lines in Puerto Rico in 1999.

\begin{tabular}{|c|c|c|c|c|c|c|c|}
\hline \multirow[b]{2}{*}{ Line } & \multirow[b]{2}{*}{$\mathrm{ST}^{1}$} & \multirow[b]{2}{*}{$\mathrm{GH}^{2}$} & \multicolumn{3}{|c|}{ Back-transformed mean seed yield } & \multirow[b]{2}{*}{$\begin{array}{c}\text { Geometric mean } \\
\text { seed yield }\end{array}$} & \multirow{2}{*}{$\begin{array}{l}\text { Back-transformed } \\
\text { mean deviations } \\
\text { from regression }\end{array}$} \\
\hline & & & Combined trials & $\begin{array}{c}\text { Non-stressed } \\
\text { trials }\end{array}$ & Stressed trials & & \\
\hline & & & $-\ldots-\ldots-n$ & $-\ldots$ & . . (kg/ha) - . & - & $-\ldots-\ldots$ \\
\hline NW 590 & PT & 2 & 292 & 540 & 160 & 464 & 10 \\
\hline Maverick & PT & 3 & 292 & 714 & 116 & 753 & 0 \\
\hline PR9764-41 & SK & 3 & 285 & 666 & 122 & 490 & 3 \\
\hline Gloria & PK & 2 & 265 & 593 & 116 & 615 & 3 \\
\hline PI 224730 & BL & 1 & 253 & 766 & 77 & 479 & -2 \\
\hline Don Silvio & SR & 3 & 236 & 607 & 88 & 590 & -2 \\
\hline A55 & BL & 2 & 219 & 480 & 97 & 393 & 2 \\
\hline Burke & PT & 3 & 209 & 480 & 88 & 550 & 0 \\
\hline NW 410 & $\mathrm{PT}$ & 3 & 204 & 593 & 66 & 518 & -5 \\
\hline Rufus & SR & 2 & 199 & 515 & 75 & 405 & -1 \\
\hline Roza & PK & 2 & 199 & 731 & 49 & 417 & -9 \\
\hline Sacramento & LK & 1 & 181 & 397 & 79 & 421 & 1 \\
\hline TARS VCI-4B & $\mathrm{PT}$ & 2 & 172 & 636 & 41 & 422 & -15 \\
\hline Arroyo Loro & SW & 2 & 172 & 967 & 23 & 274 & -29 \\
\hline NW 63 & SR & 3 & 168 & 552 & 45 & 314 & -8 \\
\hline Taylor Horticultural & $\mathrm{CR}$ & 1 & 168 & 247 & 110 & 460 & 6 \\
\hline PI $165426 \mathrm{~W}$ & SW & 3 & 149 & 176 & 128 & 268 & 19 \\
\hline
\end{tabular}

1ST (Seed Type): $\mathrm{BL}=$ black, $\mathrm{RM}=$ red mottled, $\mathrm{B}=$ beige, $\mathrm{PK}=$ pink, $\mathrm{C}=$ creme, $\mathrm{SR}=$ small red, $\mathrm{DK}=$ dark red kidney, $\mathrm{PT}=$ pinto, $\mathrm{SK}=$ striped light red kidney, $\mathrm{LK}=$ light red kidney, $\mathrm{SW}=$ small white, $\mathrm{CR}=$ cranberry, $\mathrm{TN}=\mathrm{tan}, \mathrm{SN}=$ snap bean, $\mathrm{DB}=$ dark brown, $\mathrm{W}=$ white, $\mathrm{BW}=$ black and white, and LA = lavender.

${ }^{2} \mathrm{GH}$ (Growth Habit): 1 = bush, determinate, 2 = bush, indeterminate, 3 = indeterminate prostrate with well-developed branching but low or nonexistent climbing ability, and 4 = indeterminate, with long guide and high climbing ability (Singh, 1982). 
TABLE 1. (CONTINUED) Means of seed yield of four field trials, two stressed field trials, two non-stressed field trials, the geometric mean of seed yield of two stressed and two non-stressed field trials, and mean deviations from regression for forty-eight common bean lines in Puerto Rico in 1999.

\begin{tabular}{|c|c|c|c|c|c|c|c|}
\hline \multirow[b]{2}{*}{ Line } & \multirow[b]{2}{*}{$\mathrm{ST}^{1}$} & \multirow[b]{2}{*}{$\mathrm{GH}^{2}$} & \multicolumn{3}{|c|}{ Back-transformed mean seed yield } & \multirow[b]{2}{*}{$\begin{array}{l}\text { Geometric mean } \\
\text { seed yield }\end{array}$} & \multirow{2}{*}{$\begin{array}{c}\text { Back-transformed } \\
\text { mean deviations } \\
\text { from regression }\end{array}$} \\
\hline & & & Combined trials & $\begin{array}{c}\text { Non-stressed } \\
\text { trials }\end{array}$ & Stressed trials & & \\
\hline & & & $\ldots-\ldots$ & $\ldots \ldots$ & . . . (kg/ha) - . & - . . . - . - & 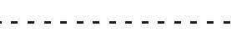 \\
\hline PI 203958 & $\mathrm{BL}$ & 4 & 135 & 95 & 194 & 299 & 27 \\
\hline Pindak & PT & 2 & 116 & 714 & 12 & 234 & -49 \\
\hline Cornell 2114-12 & $\mathrm{TN}$ & 4 & 113 & 230 & 53 & 213 & 0 \\
\hline Chinook 2000 & LK & 1 & 108 & 437 & 20 & 239 & -28 \\
\hline RRR 77 & $\mathrm{SN}$ & 1 & 90 & 185 & 40 & 173 & -1 \\
\hline Viva & PK & 3 & 88 & 515 & 8 & 90 & -41 \\
\hline PI 226895 & DB & 1 & 81 & 156 & 40 & 190 & 2 \\
\hline XR-235-1-1 & W & 2 & 61 & 135 & 25 & 109 & -1 \\
\hline USWA 27 & $\mathrm{BW}$ & 2 & 56 & 265 & 6 & 52 & -30 \\
\hline FR 266 & SN & 1 & 45 & 209 & 4 & 44 & -32 \\
\hline PI 300665 & BL & 1 & 37 & 22 & 56 & 84 & 32 \\
\hline PR9744-18 & $\mathrm{SN}$ & 1 & 28 & 58 & 12 & 46 & -1 \\
\hline PR9744-24 & SN & 1 & 22 & 53 & 7 & 43 & -4 \\
\hline PR9744-20 & $\mathrm{SN}$ & 1 & 11 & 33 & 0 & 0 & -9 \\
\hline PR9744-17 & SN & 1 & 7 & 18 & 0 & 0 & -3 \\
\hline $\mathrm{CV}(\%)$ & & & 22.0 & 15.2 & 33.3 & & 13.5 \\
\hline $\operatorname{LSR}(0.05)$ & & & 1.7 & 2.1 & 2.4 & & 2.4 \\
\hline
\end{tabular}

1ST (Seed Type): $\mathrm{BL}=$ black, $\mathrm{RM}=$ red mottled, $\mathrm{B}=$ beige, $\mathrm{PK}=$ pink, $\mathrm{C}=$ creme, $\mathrm{SR}=$ small red, $\mathrm{DK}=$ dark red kidney, $\mathrm{PT}=$ pinto, $\mathrm{SK}=$ striped light red kidney, $\mathrm{LK}=$ light red kidney, $\mathrm{SW}=$ small white, $\mathrm{CR}=$ cranberry, $\mathrm{TN}=$ tan, $\mathrm{SN}=$ snap bean, $\mathrm{DB}=$ dark brown, $\mathrm{W}=$ white, $\mathrm{BW}=$ black and white, and LA = lavender.

${ }^{2} \mathrm{GH}$ (Growth Habit): 1 = bush, determinate, 2 = bush, indeterminate, 3 = indeterminate prostrate with well-developed branching but low or nonexistent climbing ability, and $4=$ indeterminate, with long guide and high climbing ability (Singh, 1982). 
dox) soil. The Isabela planting dates were 5 January, 12 January, and 15 December 1999. These plantings were made under relatively short days (winter season) so that all genotypes would be able to produce seed. Mean high and low temperatures for the above three trials were $28.1 / 17.7,28.3 / 17.7$, and $27.3 / 18.0^{\circ} \mathrm{C}$, respectively. Total rainfall during the three trials was 181,248 , and $112 \mathrm{~mm}$, respectively.

A fourth trial was planted 1 June 1999 in Juana Díaz, Puerto Rico ( $18^{\circ} 01^{\prime} \mathrm{N}$ Latitude; $21 \mathrm{~m}$ above sea level). This planting, because of its longer photoperiod and higher temperature, most closely approximated the growing environment of temperate climates. A summer-planted evaluation is necessary in order to determine the degree of photoperiod-sensitivity among breeding lines. The soil type was a Mollisol (Cumulic Haplustolls) and the average maximum/minimum temperatures were $32.8 / 22.8^{\circ} \mathrm{C}$. Total rainfall during this trial was $226 \mathrm{~mm}$.

Alachlor (2-chloro-2'-6'-diethyl-N-(methoxymethyl)-acetanilide) (Monsanto Company, St. Louis, MO $)^{4}(7.41 \mathrm{~L} / \mathrm{ha}$, pre-plant incorporated) was applied for weed control on all plantings and was supplemented by hand weeding as necessary. Nitrogen $(90 \mathrm{~kg} / \mathrm{ha})$ as ammonium sulfate, phosphorus (10 kg/ha) as triple superphosphate, and potassium (19 kg/ ha) as potassium chloride were side dressed at the time of planting.

The 12 January and 15 December stress trials were conducted in the same field, which had been planted with common bean cultivar Arroyo Loro in previous seasons (September 1998 and June 1999). Prior to the 12 January planting, $R$. solani was isolated from tissue of Arroyo Loro growing in this field. Rhizoctonia sp. was observed in the 12 January planting and $R$. solani and $F$. solani were isolated from plants in the 15 December trial. Rhizoctonia solani was isolated from diseased plants growing in the June planting.

Immediately after sowing, the experimental area of the stressed trials was subjected to $2.3 \times 10^{5} \mathrm{~Pa}$ of pressure from the weight of a van. As a front and rear tire of the vehicle passed over each seeded row of the experimental area, the space between rows $(58 \mathrm{~cm}$ from one row and $23 \mathrm{~cm}$ from the other row) was compacted by the front and rear tire on the other side of the van. No compaction measurements were taken for these trials. However, measurements taken with a penetrometer at multiple points in the rows in a subsequent bean trial at the same experimental site, using the same compaction protocol, demonstrated

${ }_{4}^{4}$ Trade names in this publication are used only to provide specific information. Mention of a trade name or manufacturer does not constitute a warranty of equipment or materials by the USDA-ARS or the Agricultural Experiment Station of the University of Puerto Rico, nor is this mention a statement of preference over other equipment or materials. 
large differences (3.0 and $8.9 \times 10^{5} \mathrm{~Pa}$ at depths of 76 and $229 \mathrm{~mm}$, respectively) between compaction treatments.

Immediately after planting and compaction, plastic drip-irrigation tubing was installed over each row in all four trials. The soil of the two stressed trials was maintained waterlogged with drip irrigation for the first 30 days after planting. Stressed trials were irrigated as often as necessary to maintain waterlogged soils. The 5 January and June trials (non-stressed) were not subjected to compaction or an extended period of saturated soil, and did not have a previous crop of beans. They were drip irrigated as needed to avoid drought. The term "non-stressed" does not imply that the "non-stressed" trials were completely free of stress. It simply designates the two trials whose soil was not subjected to compaction, waterlogging, and a bean monoculture.

An experimental unit was defined as a single 1-m row plot with an area of $0.91 \mathrm{~m}^{2}$. Row spacing was $0.91 \mathrm{~m}$ and the seeding rate per plot was $16.4 \mathrm{seed} / \mathrm{m}^{2}$. Alleys between plots were $1 \mathrm{~m}$ and plots were not end trimmed prior to harvest. Plots were adjacent to each other in a grid (range-row) pattern. Seedling emergence, harvest-stand count, and the weight of harvested seed were measured for each plot.

Hartley's test was used to determine that trial variances for yield, emergence, and harvest-stand count were heterogeneous (Ott, 1993). A $\log (y+1)$ transformation (Steel and Torrie, 1980) was used to produce homogeneous variances in order to make statistical inferences about differences. Each trial was analyzed separately as a randomized complete block design (RCBD). Combined stressed trials, combined nonstressed trials, and combined stressed and non-stressed trials were analyzed as a RCBD for combined trials (McIntosh, 1983), where effects were fixed. Each trial had three replications. Protected LSDs $(\mathrm{P}<0.05)$ were calculated to distinguish line mean differences over all locations and within each stress treatment. Transformed yield means combined over all trials, combined over stressed trials, and combined over nonstressed trials were back-transformed for presentation in Table 1. LSDs were back-transformed to least significant ratios (LSRs). If the ratio between two means is greater than the LSR, the means are significantly different. Back-transformed means are geometric means of the original data (Steel and Torrie, 1980). Hence, no comparison of geometric and arithmetic means was made on the original scale. Statistix for Windows (Analytical Software, Tallahassee, FL) was used for statistical analyses.

Arithmetic means for each line were calculated for the stressed (y) and non-stressed $(\mathrm{z})$ treatments and then used to calculate geometric means (GM of $y$ and $\left.z=(y \times z)^{1 / 2}\right)$ (Steel and Torrie, 1980) for each line. As the back-transformed means already provide geometric means of 
the original data, geometric means of the arithmetic yield means for combined stressed and combined non-stressed trials provide a separate estimate of geometric means over all trials. Estimates of stress tolerance were made by regression analyses using transformed yield data for each line, where yield under stress (dependent variable) was regressed onto yield under non-stress (independent variable). As suggested by Beebe et al. (1997), individual plot values were used as the dependent variable, but line means (over both non-stressed trials) were used as the independent variable. Regression analyses were performed for each replication of the two stress trials, and separate slopes and intercepts were fitted for each replication. Deviations from regression for each line in each of the six replications (three replications over two trials) were calculated and then subjected to an analysis of variance according to the RCBD for the stressed trials. Back-transformed mean deviations from regression for each line were then calculated and used as the measure of genotypic stress tolerance. An LSR was calculated to differentiate means. Lines with high positive deviations from regression were considered tolerant relative to lines with high negative deviations from regression.

A $10 \%$ selection intensity for seed yield was applied to the backtransformed line means combined over trials, combined over stressed trials, and combined over non-stressed trials. A $10 \%$ selection intensity was also applied to geometric line means of stressed and non-stressed trials and to back-transformed mean deviations from regression of stressed and non-stressed trials. The number of lines selected for each selection protocol was rounded to five.

\section{RESULTS AND DISCUSSION}

Significant $(\mathrm{P}<0.05)$ trial and line differences and significant $(\mathrm{P}<$ 0.05 ) trial $\times$ line interactions were observed in the combined analysis for yield, emergence, and harvest-stand count (Table 2). These differences were related to trial stress treatment, as well as different levels of stress tolerance among lines. Also, the relative performance of some lines changed according to differences in stress treatment. Soil compaction and waterlogging increased plant stress, as noted by Thung and Rao (1999). Burke and Miller (1983) noted that flooding can nullify resistance to $F$. solani. As in many assays for tolerance to biotic and abiotic stresses, the methods used to compact and water-saturate the soil in the current study were not natural. Their purpose was to help differentiate diverse genotypes for tolerance to the biotic and abiotic stresses resulting from compaction, waterlogged soils and monoculture. The imposed stresses appeared to be effective in this differentiation. 
TABLE 2. Combined analysis of variance for transformed effects of trial and line on seed yield, emergence-stand count and harvest-stand count of 48 common bean lines grown in four trials in Puerto Rico in 1999.

\begin{tabular}{|c|c|c|c|c|}
\hline \multirow[b]{2}{*}{ Source } & \multirow[b]{2}{*}{ df } & \multicolumn{3}{|c|}{ Mean squares } \\
\hline & & Yield & Emergence & Harvest count \\
\hline & & $\mathrm{kg} / \mathrm{ha}$ & \multicolumn{2}{|c|}{ - _ - - - plants per $\mathrm{m}^{2} \ldots$} \\
\hline Trial & 3 & $50.10^{* * 1}$ & $6.13^{* * *}$ & $7.85^{* * *}$ \\
\hline Rep/trial & 8 & $0.60^{* * *}$ & $0.05 * 2$ & $0.14^{* *}$ \\
\hline Line & 47 & $2.14^{\text {*** }}$ & 0.20 *** & $0.35^{* *}$ \\
\hline Trial $\times$ line & 141 & $0.46^{\text {**** }}$ & $0.14^{* * *}$ & $0.14^{* * *}$ \\
\hline Pooled error & 376 & & & \\
\hline
\end{tabular}

${ }^{1}$ Significant at the 0.01 probability level.

${ }^{2}$ Significant at the 0.05 probability level.

Although the trial means for the two non-stressed trials were not different $(\mathrm{P}<0.05)$ from each other for seed yield ( 362 and $552 \mathrm{~kg} / \mathrm{ha}$ ), only one non-stress trial mean $(552 \mathrm{~kg} / \mathrm{ha}$ ) out-yielded $(\mathrm{P}<0.05)$ both stressed trial means (278 and $18 \mathrm{~kg} / \mathrm{ha}$ ) (Table 3 ). The 5 January non-stress trial mean (362 kg/ha) and the 12 January stress trial mean $(278 \mathrm{~kg} / \mathrm{ha})$ were not different $(\mathrm{P}<0.05)$ for seed yield, but both had higher $(\mathrm{P}<0.05)$ yield than the 15 December stress trial mean (18 kg/ha) (Table 3$)$.

Trial means for emergence of the two non-stress trials were the same (both 13.5 plants per $\mathrm{m}^{2}$ ), as were the trial means for emergence of the two stress trials (both 5.3 plants per $\mathrm{m}^{2}$ ) (Table 3). The two stress treatments were different for emergence $(\mathrm{P}<0.05)$ (Table 3$)$, with emergence being positively correlated $(r=0.63, \mathrm{P}<0.05)$ to yield over all trials. However, emergence was not always related to seed yield, as the 5 January non-stressed and the 12 January stressed trials were not different for seed yield, but were different for emergence (Table 3 ). The 15 December stress trial averaged fewer $(P<0.05)$ plants at harvest

TABLE 3. Back-transformed means of emergence-stand count, harvest-stand count, and seed yield for four trials grown in Puerto Rico in 1999.

\begin{tabular}{lccc}
\hline $\begin{array}{l}\text { Trial date, } \\
\text { stress type and location }\end{array}$ & Emergence & Harvest count & Seed yield \\
\hline & $-\ldots-\ldots$ - plants per $\mathrm{m}^{2}-\ldots \ldots$ & $\mathrm{kg} / \mathrm{ha}$ \\
5 January, non-stress, Isabela & 13.5 & 11.0 & 362 \\
1 June, non-stress, Juana Díaz & 13.5 & 9.2 & 552 \\
12 January, stress, Isabela & 5.3 & 5.2 & 278 \\
15 December, stress, Isabela & 5.3 & 2.7 & 18 \\
LSR (0.05) & 1.2 & 1.3 & 1.6 \\
\hline
\end{tabular}


(2.7 plants per $\mathrm{m}^{2}$ ) than any other trial and was significantly lower in yield $(18 \mathrm{~kg} / \mathrm{ha}$ ) than any other trial (Table 3$)$. Over all trials, there was a high correlation $(\mathrm{r}=0.80, \mathrm{P}<0.05)$ between seed yield and harvest stand count. The plant loss that occurred after emergence in the $15 \mathrm{De}-$ cember stress trial may have been related to an increase in soil pathogens that occurred between the January and December stress trials. Fusarium solani was recovered only from plants in this trial, which occurred at the same location as the previous year's stress trial. Continued monocropping may have affected the location's soil pathogens and adversely affected its seed yield through a reduction in plant stand. Burke and Kraft (1974) found increased incidence of $F$. solani and $R$. solani in bean-monocropped fields compared to that in controls, and Thung and Rao (1999) noted reduced yield over time in beanmonocropped systems. Hence, compacted and waterlogged soils in a bean monoculture generally resulted in lower emergence scores, fewer plants at harvest, and lower seed yield.

Combined back-transformed trial means for yield ranged from seven to $1,013 \mathrm{~kg} / \mathrm{ha}$, with continuous variation between the high and low (Table 1). The yield CV for the combined non-stressed trials was 15.2, whereas the CV for the combined stressed trials was double (33.3) that of the non-stressed trials (Table 1). Stress caused low yield means, and thus contributed to the higher CV. Schneider et al. (1997) reported CVs of 28.7 and 28.2 for two populations tested for seed yield under drought stress, and 23.6 and 24.4 for the same two populations, respectively, under non-drought stress.

When a $10 \%$ selection intensity was applied to the lines ranked by back-transformed mean yield (for combined trials) or geometric mean yield (derived from arithmetic means), the same four highest yielding lines were selected: 'G21212,' 'T-39,' 'MUS PM-31,' and 'XAN 176,' (Table 1). The fifth selection was 'A300' and 'Rosita' for the backtransformed and geometric means, respectively. When selection was based only on data from non-stressed trials, MUS PM-31 and Rosita from the back-transformed and geometric means, respectively, were replaced by 'DOR 364' (Table 1). When selection was based only on data from stressed trials, selected lines were G21212, MUS PM-31, T-39, PI 312033 ('Frijol Negro'), and 'Porrillo Sintético' (Table 1). Hence, stress treatment affected which lines were selected and likely provides the best explanation for the significant trial $\times$ line interaction noted above. Some lines were more stress tolerant and adapted than others.

Selecting five lines based on the highest back-transformed mean deviation from regression resulted in the following selections: 'PI 300665,' MUS PM-31, T-39, PI 312033, and 'PI 203958.' Hence, selection protocol also affected which lines were selected. However, PI 203958 should be 
excluded from this list because its mean deviation from regression was biased upward because of its photoperiod sensitivity and thus poor yield in the June trial (non-stressed). G21212, the entry with the next highest mean deviation from regression (Table 1), was not biased by photoperiod sensitivity and therefore should replace PI 203958 as a selection.

When two rounds of selection were followed as recommended by Schneider et al. (1997), using geometric means in the first round and stressed back-transformed means in the second, the selected lines were the same as when selection was based only on stressed yield data (G21212, MUS PM-31, T-39, PI 312033, and Porrillo Sintético). For this latter geometric mean selection strategy, a $20 \%$ selection intensity was used for the first round (10 lines selected) and a 50\% selection intensity was used in the second round.

It should be noted that Schneider et al. (1997) combined stressed and non-stressed treatments within a trial, but the current study did not. Separate stressed and non-stressed trials contributed to the heterogeneous variances observed among trials in the current study, all of which necessitated the transformation of data and back-transformation of means for presentation. The resulting use of geometric (backtransformed) means might routinely be expected from analyses of stressed and non-stressed trials, as heterogeneous variances might routinely be expected in most such cases. Heterogeneous trial variances might be avoided by including, where possible, stressed and nonstressed treatments within a single trial. Also, the use of arithmetic means from multiple stress trials to calculate a geometric mean could inflate the geometric mean because of one trial having significantly less stress and thus higher yield. Less variation might be expected from geometric means calculated from a single trial containing both stressed and non-stressed plots. However, multiple stressed and non-stressed trials are still needed to ensure the best estimate of the geometric mean. And as the number of trials increases, so will the variation associated with the estimated geometric mean. Even with trials containing both stressed and non-stressed plots, inflation of the geometric mean can occur, as multiple trials may significantly differ for level of stress. Further, it may be difficult to apply stressed (e.g., monoculture, waterlogging, compaction, drought, heat) and non-stressed plots to a single trial and the presumed value of doing so may not be sufficient to warrant the effort, especially for initial yield trials of single-plant-derived progenies. The use of transformations and back-transformations (and resulting geometric means) is sufficiently straightforward to resolve the problem of heterogeneous trial variances. Therefore, whether geometric means (back-transformed means) are used, or geometric means 
of stressed and non-stressed treatments within a single trial [as recommended by Schneider et al. (1997)] are used, geometric means are appropriate for combining stressed and non-stressed yield data.

Selection under stress was similar to selection for positive deviations from regression, except that PI 300665 was selected by the regression approach, but not by seed yield under stress. PI 300665 had low but stable seed yield and highlights a potential yield drawback for using deviations from regression as a sole selection criterion. 'PI $165426 \mathrm{~W}$ ' also had a high positive mean deviation from regression, but not high seed yield (Table 1). Resistance to soil pathogens may have affected stress tolerance in PI 300665, since this line has resistance to R. solani (Prasad and Weigle, 1970).

Two lines, G21212 and T-39, were selected in the top 10\% for each selection protocol. They yielded higher under stress, under non-stress, over combined treatments, and were among the lines with the highest positive deviations from regression. Both are small seeded and black. T-39 has resistance to $F$. solani (Schneider and Kelly, 2000), and G21212 is intermediate for resistance to $R$. solani (Canaday et al., 2002). G21212 has been noted for its adaptation to low phosphorus supply in soils (Rao et al., 1998; Rao et al., 1999), its excellent adventitious root development (S. Beebe, personal communication, 1998), and a capacity for exceptional translocation of photosynthates (Beebe and Terán, 2000). Kahn et al. (1985) found that T-39 was capable of adventitious root production under flood stress. Such newly formed adventitious roots may have well developed aerenchyma and be better able to grow in anaerobic soil (Marschner, 1986). VanToai et al. (1994) found that flood tolerance was independent of Phytophthora tolerance and Phytophthora resistance in soybean. Hence, it is possible that both resistance to soil pathogens and stress-adaptive responses were important factors in promoting the yield potential of these lines across environments. It is also interesting to note that four of the five lines selected under stress conditions (G21212, T-39, PI 312033, and Porrillo Sintético) are black seeded and have some resistance to soil pathogens. PI 312033 has resistance to $F$. solani, and Porrillo Sintético has resistance to $F$. solani and $R$. solani (Beebe et al., 1981).

Although G21212 and T-39 would have been selected by using either of the above selection strategies, a majority of the lines would not. DOR 364 was selected only under non-stress conditions, whereas PI 312033 and Porrillo Sintético were selected only under stress conditions. XAN 176 and A300 were not selected under stress, and MUS PM-31 was not selected under non-stress. Hence, selection environment affected which lines were selected. Therefore, the best evaluation of material is most likely when selection is based on both stressed and non-stressed yields. 
None of the highest yielding lines had a determinate growth habit. This finding agrees with several studies cited by Kelly et al. (1999). Lines with an indeterminate growth habit generally yield higher than those with a determinate growth habit. Hence, selection for the highest yielding type I lines, if desired, should be practiced apart from that of other growth habit types.

The purpose of this study was to compare the value of using geometric means versus deviations from regression for making selections among a group of highly heterogeneous lines of common bean. Geometric means better account for large differences in yield performance between stressed and non-stressed environments than do arithmetic means (Schneider et al., 1997). They ensure that a selected genotype has yield potential and that it can maintain its yield potential under stress. Selecting for high positive deviations from regression measures only relative stress tolerance. Deviations from regression do not take into account base yield potential (non-deviations from regression). Their values are always relative to the genotypes measured and may change as entries are added or subtracted. Geometric means, however, remain the same for a given genotype, regardless of additions or deletions from the entry list. If the goal of a research program is only to determine the highest yielding lines across multiple varied environments, then backtransformed combined means (geometric means) or geometric means derived from arithmetic means are recommended as superior to mean deviations from regression. However, an important contribution of deviations from regression may be in identifying stress-tolerant lines, which would otherwise be discarded because of intrinsic low-yield potential. Wide crosses will create new genetic combinations, and deviations from regression could help to identify new sources of stress tolerance in these populations. Instead of being discarded, newly created gene combinations providing stress tolerance could be further studied and introgressed into better genetic backgrounds. Otherwise, many potentially valuable new gene combinations created at the base and intermediate levels may not survive to be introgressed into the apex level of the breeding pyramid. Perhaps deviations from regression could be utilized most effectively at the base and intermediate levels, whereas geometric means could be utilized higher in the breeding pyramid.

\section{CONCLUSIONS}

Stress imposed by compaction, waterlogging, and monoculture reduced seed yield compared to that of non-stress. Yield selection using geometric means of stressed and non-stressed trials and back-transformed means of stressed and non-stressed trials were both effective in 
selecting the best lines among this set of 48 lines. The two-stage geometric mean selection strategy of Schneider et al. (1997) selected the same lines as selection under stress. Combined means (back-transformed or geometric) of stressed and non-stressed yield trials are preferable to deviations from regression for selecting the highest yielding lines. However, deviations from regression may be useful in identifying useful stress-tolerant lines that might otherwise be discarded, or in identifying unique stress tolerance mechanisms for further investigation.

Selection protocol and environment affected which lines were selected. Highly diverse bean lines can be effectively evaluated in short single-row plots. On the basis of this evaluation of 48 diverse bean lines, geometric means of multiple environments (stressed and nonstressed) are recommended for the evaluation of highly diverse bean lines and are proposed for evaluating highly diverse bean progenies from wide crosses.

\section{LITERATURE CITED}

Beebe, S. E. and M. Pastor Corrales, 1991. Breeding for disease resistance. pp. 561-617. In A. Van Schoonhoven and O. Voysest (eds.). Common Beans, Research for Crop Improvement. CAB International. Oxon, UK.

Beebe, S. E. and H. Terán, 2000. Combination of traits and genes for abiotic stress tolerance. pp. 7-8. In: A. L. Jones (ed.). Annual Report 1999, Project IP-1; Working document No. 180. CIAT. Cali, Colombia.

Beebe, S. E., F. A. Bliss and H. F. Schwartz, 1981. Root rot resistance in common bean germplasm of Latin American origin. Plant Disease 65:485-489.

Beebe, S., J. Lynch, N. Galwey, J. Tohme and I. Ochoa, 1997. A geographical approach to identify phosphorous-efficient genotypes among land races and wild ancestors of common bean. Euphytica 95:325-336.

Burke, D. W. and J. M. Kraft, 1974. Responses of beans and peas to root pathogens accumulated during monoculture of each crop species. Phytopathology 64:546-549.

Burke, D. W. and D. E. Miller, 1983. Control of Fusarium root rot with resistant beans and cultural management. Plant Disease 67:1312-1317.

Canaday, C. H., J. E. Wyatt, J. Bohac and J. R. Smith, 2002. Field evaluation of bean cultivars and lines for resistance to Rhizoctonia, 2001. Biol. and Cult. Tests 17:V02.

Forster, R. L., J. R. Steadman and H. F. Schwartz, 2000. Integrated management of bean diseases. pp. 101-112. In: S. P. Singh (ed.). Bean Research, Production and Utilization; Proceedings of the Idaho Bean Workshop. Ag Communications. Kimberly, Idaho.

Galwey, N. W. and A. M. Evans, 1982. Alternative methods of interpreting measurements of resistance to the leafhopper Empoasca kraemeri Ross and Moore in the common bean, Phaseolus vulgaris L. Euphytica 31:225-236.

Green, D. E., R. M. Shibles and B. J. Moraghan, 1974. Use of hill-plots and short rows to predict soybean performance under wide- and narrow-row management. Iowa State J. Res. 49:39-46.

Kahn, B. A., P. J. Stofella, R. F. Sandsted and R. U. Zobel, 1985. Influence of flooding on root morphological components of young black beans. J. Am. Soc. Hort. Sci. 110:623-627. 
Kelly, J. D., J. M. Kolkman and K. Schneider, 1998. Breeding for yield in dry bean (Phaseolus vulgaris L.). Euphytica 102:343-356.

Kelly, J. D., K. A. Schneider and J. M. Kolkman, 1999. Breeding to improve yield. pp. 185-222. In: S. P. Singh (ed.). Common Bean Improvement in the Twenty-First Century. Kluwer Academic Publishers. Boston, MA.

Marschner, H., 1986. Mineral Nutrition of Higher Plants. Academic Press. London, England.

McIntosh, M. S., 1983. Analysis of combined experiments. Agron. J. 75:153-155.

Miklas, P. N., 2000. Use of Phaseolus germplasm in breeding pinto, great northern, pink, and red bean for the Pacific Northwest and Intermountain Region. pp. 331370. In: S. P. Singh (ed.). Bean Research, Production and Utilization; Proceedings of the Idaho Bean Workshop. Ag Communications. Kimberly, ID.

Ott, L., 1993. An Introduction to Statistical Methods and Data Analysis. $4^{\text {th }}$ Edition. Wadsworth, Inc. Belmont, CA.

Prasad, K. and J. L. Weigle, 1970. Screening for resistance to Rhizoctonia solani in Phaseolus vulgaris. Plant Dis. Rep. 54:40-44.

Rao, I. M., J. Ribet, S. Beebe and J. Ricaurte, 1998. Identifying plant traits and mechanisms for tolerance to low P. pp. 18-28. In: Bean Project Annual Report, 1997; Working Document No. 177. CIAT. Cali, Colombia.

Rao, I. M., S. P. Singh, J. Ricaurte and H. Terán, 1999. Identifying aluminum tolerant and nutrient efficient bean genotypes. pp. 23-16. In: A. L. Jones (ed.). Bean Project Annual Report, 1998; Working Document No. 179. CIAT. Cali, Colombia.

Rosielle, A. A. and J. Hamblin, 1981. Theoretical aspects of selection for yield in stress and non-stress environments. Crop Sci. 21:943-946.

Schneider, K. A. and J. D. Kelly, 2000. A greenhouse screening protocol for Fusarium root rot in bean. HortSci. 35:1095-1098.

Schneider, K. A., R. Rosales-Serna, F. Ibarra-Pérez, B. Cazares-Enrique, J. A. AcostaGallegos, P. Ramirez-Vallejo, N. Wassimi and J. D. Kelly, 1997. Improving common bean performance under drought stress. Crop Sci. 37:43-50.

Singh, S. P., 1982. A key for identification of different growth habits of Phaseolus vulgaris L. Ann. Rep. Bean Improv. Coop. 25:92-95.

St. Martin, S. K., B. W. Dye and B. A. McBlain, 1990. Use of hill and short-row plots for selection of soybean genotypes. Crop Sci. 30:74-79.

Steel, R. G. D. and J. H. Torrie, 1980. Principles and Procedures of Statistics. 2nd Edition. MeGraw Hill Book Company. New York, NY.

Thung, M. and I. M. Rao, 1999. Integrated management of abiotie stresses. pp. 331-370. In: S. P. Singh (ed.). Common Bean Improvement in the Twenty-First Century. Kluwer Academic Publishers. Boston, MA.

VanToai, T. T., J. E. Beuerlein, A. F. Schmitthenner and S. K. St. Martin, 1994. Genetic variability for flooding tolerance in soybeans. Crop Sci. 34:1112-1115. 
